\title{
Physical Education: Adaptations and Benefits for Deaf Students
}

\author{
Clévia Fernanda Sies Barboza ${ }^{1}$, Alex Sandro Lins Ramos ${ }^{1}$, Paula Alvarez Abreu ${ }^{2}$, \\ Helena Carla Castro ${ }^{*}$
}

${ }^{1}$ Laboratório de Antibióticos Bioquímica, Ensino e Modelagem Molecular (LabieMol), Instituto de Biologia, Universidade Federal Fluminense, Campus Valonguinho, Niterói, Brazil

${ }^{2}$ Laboratório de Modelagem Molecular e Pesquisa em Ciências Farmacêuticas, Instituto de Biodiversidade e Sustentabilidade, Universidade Federal do Rio de Janeiro, Macaé, Brazil

Email: *hcastrorangel@yahoo.com.br

How to cite this paper: Barboza, C. F. S., Ramos, A. S. L., Abreu, P. A., \& Castro, H. C. (2019). Physical Education: Adaptations and Benefits for Deaf Students. Creative Education, 10, 714-725. https://doi.org/10.4236/ce.2019.104053

Received: February 11, 2019

Accepted: April 16, 2019

Published: April 19, 2019

Copyright (c) 2019 by author(s) and Scientific Research Publishing Inc. This work is licensed under the Creative Commons Attribution International License (CC BY 4.0).

http://creativecommons.org/licenses/by/4.0/

\begin{abstract}
Human development encompasses a relationship between genetics and environment factors including affective, social, cognitive and motor development. Physical activity can reduce the risk of several diseases also stimulating health promotion, feelings expression, formation of critical awareness, autonomy development, motivation for study and others. In case of deaf students, physical education also has other benefits, including social inclusion. Many challenges need to be overcome on adapted physical education for deaf students such as the lack of bilingual teachers and also the lack of specific signs of some important words for physical education. Herein we reviewed the benefits of physical activity for deaf children, highlighting some adaptations for helping on teaching and learning and development of this public.
\end{abstract}

\section{Keywords}

Deafness, Inclusion, Physical Activity, Physical Education, Teaching

\section{Introduction}

Physical education (PE) is a very important discipline since it helps on the development of students' cognitive abilities and motor skills, also affecting children's decisions and behavior about their own health (Chen et al., 2018; Ennis, 2007). Most of teaching and learning process regarding this discipline focus on a perspective of physical aptitude and motor learning, while others reflect the social and historic contextualization. The terms "body culture", "body movement culture" and "movement culture" were created to support a new view of physical 
education. On that new perspective, the concept of culture gains more importance and redefine the relationship among physical education, body nature and knowledgement (Kunz, 1991; Mendes \& Nobrega, 2009; Bracht, 2005). Human development is linked to endogenous factors such as: genetics, ethnicity, hormones, among others (Stafford, 2005) also including exogenous or environmental factors such as nutrition and physical activity (Lima et al., 2001). Currently, the Dynamic Systems Theory is used to study human development. Dynamic systems are systems of elements that change constantly. This theory states that through self-organization, it is possible to understand the emergence of new behaviors within motor development through dynamic relationships between humans and the environment. The areas of application include motor development, perceptive and cognitive development, and social development (Gorla \& Araujo, 2007; Haywood, 1986; Smith \& Thelen, 1993).

The motor development constraints involve the dynamic relationships among environment, person and motor task, being relevant to understand the development itself (Manoel, 1996; Newell, 1993). Literature describes that the continuous process of motor development goes from simple and unorganized movements to complex abilities, from birth to death (Haywood, 1986). Organisms in development are complex as they are constituted of many components, which are in continuous interaction among them and with the environment. These interactions may cause changes in components and in the whole system, which is called multicausality. According to Smith \& Thelen (1993), the development can be described as a series of evolving and dissolving patterns of varying dynamic stability, and are not an inevitable march toward maturity (Serbetar, 2014).

\section{Benefits of Physical Activity for Deaf Children}

The definition of Physical activity may vary and one of them is that physical activity is the body movement produced by skeletal muscle that increases energy expenditure. It is linked to the improvement of human psychic, affective, social, cognitive and motor development. Many studies have shown that moderate-intensity physical activities have significant health benefits (WHO, 2019; Caspersen, Powell, \& Christenson, 1985; Zeng et al., 2017).

Physical activity reduces the risk of cardiovascular disease, diabetes, depression, obesity; while the lack of physical activity increases it (WHO, 2019; Kohl III \& Cook, 2013). Even in case of patients with specific disorders (e.g. cancer or diabetes) physical activity may bring beneficial effects such as reducing fatigue, improving physical condition, mood and quality of life, helping with cardiovascular integrity, insulin sensitivity, and others (Beuchat-Mamie et al., 2018; Melmer, et al., 2018; Squires, et al., 2018). Thus these activities may bring psychological and physiological benefits (e.g. health promotion, feelings expression, formation of critical awareness, autonomy development, and motivation for study, among others) (Munoz et al., 2004; Pettersson, 2000; Sarma, 2017; Mavilidi et al., 2018). 
Physical activity can be carried out without restriction by the deaf population. Deaf generally refers to a person who is unable to hear and process information by hearing process. The bilateral hearing loss is: 1) severe when the loss is between $70-89 \mathrm{~dB}$, and 2) profound when the loss is higher than $90 \mathrm{~dB}$ loss (Hoffman et al., 2010; Ercan et al., 2016). A deaf child cannot hear and thus, is not able to spontaneously learn how to talk and comprehend speech (Mayberry, 2002; Hoffman et al., 2010). Commonly deafness is related only to hearing loss, and does not affect the capacity for practicing physical activity (Barboza et al., 2015).

Initially, Deafness restrains the development of spoken language and cognitive development (which is complex and diverse) will depend on how the family and society react to and interact with deaf children (Mayberry, 2002). According to the literature, deaf children of deaf parents show better performance academically, linguistically and socially in comparison to deaf children of hearing parents. However, according to Lieberman et al. (2004), motor development shows no significant difference between these two groups.

Studies have shown that deafness is usually followed by impairment of the vestibular system (Crowe \& Horak, 1988). Thus postural control deficits are not uncommon (Azevedo \& Samelli, 2009). In children, the relationship between loss of balance and deafness is clearly observed. Close to the age of ten years, a good control of the body by the deaf is achieved, due to a more effective integration between the visual and proprioceptive systems (Gimenez, 2005; Kaga, 2008).

Balance-related motor development is different in the deaf child and teenagers regarding the static equilibrium. In the absence of visual cues (i.e. closed eyes), the balance becomes even more compromised and the dynamic balance will present deficits in these individuals. According to some authors, the recovered balance $\left(180^{\circ}\right.$ turn) also appears better in hearing than in the deaf people (Azevedo \& Samelli, 2009). Deaf children may have problems in performing some motor tasks as: maintaining balance on chosen leg, jumping and clapping one's hands over the head and walking linear foot by foot (Brunt \& Broadhead, 1982, Zwierzchowska, Gawlik, \& Grabara, 2004). Thus, studies have detached the importance of early intervention to address the balance deficit in deaf children (Ebrahimi et al., 2017). These differences can be minimized by practicing physical activities that lead deaf children learning to compensate the vestibular deficit, adapting to it with the information received by other senses (Almeida, 2000). Since balance is a trainable skill, physical experiences through physical education classes can minimize the differences between deaf and hearing body response. Posture strategies are often developed by the deaf as a way to compensate their lack of balance. On that purpose, specific training should also be added to the classes, providing an improvement in their motor development and quality of life (Azevedo \& Samelli, 2009). Lewis et al. (1985) evaluated the effects of an exercise program following 6-week in improving balance and equilibrium in hearing-impaired children. The improvement in the balance of the experimental group demonstrates the beneficial effect of this program. Majlesi et al. (2014) 
evaluated the effects of an interventional proprioceptive training and concluded that the exercise program increased somatosensory ability and improved balance in deaf children.

\section{Deaf Education: The Achievements and Challenges}

Many changes related to deaf education have occurred worldwide. In the sixteenth century, the first attempts to stimulate the deafs to learn lip-reading were initiated. In 1755, in France, the first school for deaf was created (Rocha, 1997). Abbé Charles-Michel del'Épée was a philanthropic educator of 18th-century in France and is considered the "father of the deafs". He used the signs made by children, adding and adapting others to French terms and grammatical elements (Reis, 1992). Desloges was the first deaf to divulge the existence of a French sign language in 1779 (Armstrong \& Wilcox, 2007). In the United States, the gestural method coming from France was implemented by Thomas Gallaudet in 1816 by the creation of the Gallaudet institution (Reis, 1992).

The $19^{\text {th }}$ century is recognized as the Oralism period as sign language was disqualified for teaching deaf people in 1880 at the International Congress of Deaf people in Milan (Rocha, 1997). At this event, the deafs did not have the right to vote, resulting in 160 votes for Oralism and only 4 for the Sign Language (Rocha, 1997; Gomes, 2010).

In 1960, Stokoe conducted studies in the United States that demonstrated that the "gestures" of the deaf were not mimic, but a structured language code with rules for word and phrases construction. These rules obeyed a grammar of their own, which allowed the attribution of gestures used by the deaf to the status of a language (Gomes, 2010).

In the twentieth century, the Total Communication or Bimodalism which uses the oral and sign languages simultaneously appeared, but the main criticism was the difficult to learn both languages (Brito, 1993; Reis, 1992). Currently, given the importance of learning the natural sign language, the Bilingual approach is the main strategy requested by deaf community for deaf education in several countries. This approach proposes the learning of the two languages: the Sign Language as L1, and the Language of the hearing community where the deaf person is inserted, as L2.

According to Quadros (1997), the children acquire their first language naturally and spontaneously through the visual sense, and this language is not taught. No one teaches anyone to speak; we simply learn how to speak by ourselves. Since the deaf individual is deprived of the auditory sense, they cannot acquire the speak language in a natural way, Thus, this acquisition will take place artificially, as a second language. Similarly, no one teaches signaling; but in a natural way deaf children learn how to sign.

Quadros (1997) discussed that when the hearing children get to school, they already know how to talk the country oral language. Analogously, deaf children from deaf parents naturally have learned their country Sign Language. There- 
fore, this is the L1 of these children. However, most deaf children have hearing parents and usually have no opportunity to develop Sign Language as L1. Consequently, they get into school without knowing well any language. Thus, considering the school environment, all efforts must be made to help deaf children acquire a language (Quadros, 1997). According to Pedreira (2007), the earlier the child acquires a language, in case of deaf children the Sign Language, the more efficiently he/she can construct his/her identity, interact, understand and construct meanings of the social world. Regarding teaching physical education, one of the factors that most compromise the learning process of deaf students is the lack of knowledge of a Sign Language by many teachers, and the restricted number of signs regarding the sports subjects, as occurs in case of the Brazilian sign language (LIBRAS) (Rizkallah, 1991). Thus, it is difficult, for example, to guarantee accessibility to major sporting events and develop athletic vocations without the signs about physical activity and physical education.

Barboza et al. (2015) searched for the signs of 33 Olympic sports in LIBRAS and found only 10 signs available online. Among these, misrepresentation and inaccurate signs were also observed. The comparison with American Sign Language, Spain Sign Language and France Sign Language showed also inconsistencies in these languages regarding these sports. This may also compromise teaching physical education.

Studies recommend some strategies for the physical education teacher to communicate with the deaf students as: to speak face to face to stimulate lip reading; to use facial expressions and gestures; to be positioned in a place to garantee visual contact (Auxter et al., 2010; Munster, 2011). But it is not clear if only these estrategies will make the deaf students participate and learn from the same activities than the students without disabilities (Fiorini \& Manzini, 2018). Lip reading for example, depends on the conditions of visibility and luminosity; and demands the understanding of the context by the deaf. According to Samuelsson \& Rönnberg, 1991, only 5\% of words in phrases are correctly identified by lip reading (Ortiz, 2008).

The presence of a bilingual teacher which may represent the better scenario is rare, not only in physical education area, but also in other educational areas and sometimes deaf students were limited to copy teacher demonstration in physical education classes (Quadros, 1997).

Kurkova et al. (2010) found in their study some challenges for physical education classes as the ratio of students-teachers, and the potential risks involved in several activities during the classes. Fiorini and Manzini (2016) also used a questionnaire to evaluate the conceptual of physical education teachers about inclusion of the student with disability. In teachers' opinion, the deaf students were not considered by the teachers as the most difficult students to include in the classes; those with visual disabilities were cited as the most difficult to include. Besides, the majority of the participants believe the strategies and materials used in the classes should not be the same for students with or without disabilities. Haegele, 
Hodge, and Filho (2018) evaluated the attitudes of Brazilian physical education teachers about inclusion and found that they accept students with disabilities in their classes. Despite they were undecided about inclusion; they think that more professional training is necessary in case of attending deaf students.

\section{Adapted Physical Education for Deafs}

Physical Education can contribute to promote inclusion in schools. An inclusive school must accept, welcome and educate all students, including those with special educational needs (Mantoan, 2009). It is necessary to understand the participation and valorization of each student. In this aspect, teachers must understand the limitations, the difficulties, as well as the qualities and capacities of each of them in the various activities applied (Cavalcante, 2007).

The ideal physical education environment is the one where physical education teachers help students to enjoy physical activity, promoting a healthy life style and fitness. For many students the physical education classes are the only moment of physical activity during the day (Stewart \& Ellis, 1999; Zaccagnini, 2005). In case of deaf students, the benefits from physical education could be improved with some adaptations. The strategies for teaching deaf students should also consider the instruction of the activities and communication with the deaf students. In some cases the teacher should change the rules of the activity to avoid the exclusion of these students (Lieberman \& Cowart, 1996). According to Fiorini \& Manzini (2018) the better estrategies to promote the participation of the deaf students in the same activities as the others are those simple activities with a teaching purpose and that respected the characteristics, needs and potentialities of these students.

Adaptations in the physical education can improve the benefits for deaf students in many aspects, as for example Lieberman reported a case of a deaf student that despite the instructions of an interpreter, always waits the other students do the activity to follow them. The teacher realized that she has never asked to be a captain. So, they planned leadership opportunities for her as leding the stretching class, being a squad leader for the obstacle course unit and others. The leadership opportunity may improve the self-esteem, and self-perception of these students (Sherrill, 2004).

Physical education classes for deaf students should be differentiated, oriented and supervised. Instead of sound tracks, such as the whistle, some visual cues should be used, such as images, flags, and demonstration materials (Table 1). It is interesting to consider the theory of dynamic systems in the sense of the deaf person interaction with the visual environment in which they are inserted, thus respecting their auditory limitations (Barboza, Campello, \& Castro, 2015). There are two fundamental changes that characterize motor development: increased diversification and complexity (Connolly, 1970).

Rhythmic coordination activities can be proposed for deaf students, with or without using music. Music is always related to the sounds perception and, 
Table 1. Adaptations in physical education classes for deaf students.

\begin{tabular}{cc}
\hline IDEAL & NOT IDEAL \\
\hline Practicality & Sound tracks \\
Visual cues & Signal shortage or use of Texts \\
Knowledge of Sign language by the deaf & Lack of Sign language by the deaf \\
Bilingual Professor & Use of Interpreter or speaking slowly \\
Diversity of deaf oriented activities & Copy hearing activity \\
Teaching sociocultural values & Focus only on physical and motor skills \\
Safety for hearing aids and cochlear implants & Not being aware of possible danger and risks
\end{tabular}

seems to be incompatible to hearing impairment. Despite of that, the deaf people feel music perceiving the sound vibrations. Thus, an alternative notion of music was created mainly based on the visual domain and the tactile perception of sounds vibrations (Mithen, 2005; Zaghetto, 2013).

There is a current need for teachers that work with diversity and inclusion perspectives in physical education area. Teachers that use sign language fluently maintain a direct communication with deaf students, with clear dialogues, which allow these students to have more confidence. These teachers can facilitate the deaf-hearing interaction by obtaining a true inclusion in the class through the use of tools and strategies oriented to the specific needs of the deaf student (Mourão, 2008).

A sense of belonging to a community, of being accepted and accepting the others, of recognizing and being fully recognized generally involves language (Quadros, 1997).

Deaf students enrolled in regular classes feel valued when teacher and other colleagues know or want to learn sign language. Thus, the social interaction must be prioritized and stimulated by all teachers, including physical education teachers, creating an inclusive environment in all possible aspects. Motivated teachers (with knowledge and skills to teach deaf students) are also essential. As well as in case of children with other disabilities to guarantee the quality of the classes, health and safety (Kurkova, Scheetz, \& Stelzer, 2010; Clark, 1995).

In case of missing signs, the problem is huge for teaching physical education. It is important to develop signs for each sport involving the iconic aspect of the movement of each sport, thus, allowing accessibility to the deaf community (Frydrych, 2012). In addition, the safety issue should also be considered. Some deaf students have hearing aids and cochlear implants, thus they should be careful not to break them. Contact sports, impacts near the ear, slips and falls may damage the implant. If it happens, a new implant and surgery will be needed and it is unknown if the new implant will function as the previous one (FDA, 2018).

\section{Final Considerations}

Deaf children can and should practice physical activities, and many benefits had 
been described in the literature such as locomotor, cognitive, psychic and social development. High quality physical exercises may contribute to the better functioning of the respiratory system as well as rhythm and balance development. However, when faced with the reality of inclusion in the school, there is a lack of physical education teaching materials to work with the deaf, especially those that consider their native language (Sign language), visual-motor nature or bilingualism. There are many issues that still need to be addressed and studied in the future, such as the efficacy of some proposed strategies of adapted physical education for inclusion, the evaluation of larger groups of deaf students in more schools, in more countries with different cultures and sign languages, the analysis of the activity considering the feedback from the deaf children, as many studies were done with the physical education teacher. Studies may also compare the efficacy of an activity done with the deaf students by a bilingual teacher or a non-bilingual one. In parallel more training for physical education teachers to acquire knowledgement and skills, besides the motivation to follow in inclusion is also needed.

Importantly, this review presents considerations about the benefits of physical education for deaf students with practical significance in disseminating information to physical education teachers and other people who are interested in this theme, which may contribute to inclusion; the limitations are the few studies in this theme and the lack of more profound evaluation of the strategies to guarantee inclusion in physical education classes, as most of the studies are only reporting the modifications done. Adapted physical education can be used to motivate and stimulate deaf students to perform social interaction with other students and vice-versa. Thus, physical education classes for these students should allow a differentiated instruction, and the knowledge of sign language by their teachers is essential to achieve a direct communication within this public, creating a true inclusive environment.

\section{Acknowledgements}

We thank to FAPERJ, CAPES, and CNPq for the fellowships and financial support.

\section{Conflicts of Interest}

The authors declare no conflicts of interest regarding the publication of this paper.

\section{References}

Almeida, A. C. (2000). Surdez, paixão e dança. São Paulo: Olho dágua.

Armstrong, D. F., \& Wilcox, S. E. (2007). The Gestural Origin of Language. New York: Oxford University Press. https://doi.org/10.1093/acprof:oso/9780195163483.001.0001

Auxter, D., Pyfer, J., Zittel, L., Roth, K., \& Huettig, C. (2010). Principles and Methods of Adapted Physical Education and Recreation (11th ed.). New York: McGraw-Hill.

Azevedo, M. G., \& Samelli, A. G. (2009). Comparative Study of Balance on Deaf and 
Hearing Children. Revista CEFAC, 11, 85-91.

Barboza, C. F. S., Campello, A. R., \& Castro, H. C. (2015). Sports, Physical Education, Olympic Games and Brazil: The Deafness That Still Should Be Listened. Creative Education, 6, 1386-1390. https://doi.org/10.4236/ce.2015.612138

Beuchat-Mamie, S., Sperisen, N., \& Koçer, S. (2018). Physical Activity and Cancer. Praxis, 107, 965-970. https://doi.org/10.1024/1661-8157/a003064

Bracht, V. (2005). Cultura Corporal, Cultura de Movimento ou Cultura Corporal de Movimento? In J. M. Souza (Ed.), Educação Física Escolar: Teoria e política curricular, saberes escolares e proposta pedagógica (pp. 97-106). Recife: EDUPE.

Brito, L. F. (1993). Integração social e educação de surdos. Rio de Janeiro: Babel.

Brunt, D., \& Broadhead, G. D. (1982). Motor Proficiency Traits of Deaf Children. Research Quarterly, 53, 236-238.

Caspersen, C. J., Powell, K. E., \& Christenson, G. M. (1985). Physical Activity, Exercise and Physical Fitness: Definitions and Distinctions for Health-Related Research. Public Health Reports, 100, 126-131.

Cavalcante, M. S. A. O. (2007). Qualidade e Cidadania nas Reformas da Educação Brasileira: $O$ simulacro de um discurso modernizador. Maceió: EDUFAL.

Chen, S., Zhu, X., Androzzi, J., \& Nam, Y. (2018). Evolution of a Concept-Based Physical Education Unit for Energy Balance Education. Journal of Sport and Health Science, 7, 353-362. https://doi.org/10.1016/j.jshs.2016.06.011

Clark, J. K. (1995). Health Education Curricula in Residential Schools for the Deaf American. Annals of Deaf, 140, 410-414. https://doi.org/10.1353/aad.2012.0323

Connolly, K. J. (1970). Mechanism of Motor Skill Development. London: Academic Press.

Crowe, T. K., \& Horak, F. B. (1988). Motor Proficiency Associated with Vestibular Deficits in Children with Hearing Impairments. Physical Therapy, 68, 1493-1499.

Ebrahimi, A., Movallali, G., Jamshidi, A., Rahgozar, M., \& Haghgoo, H. (2017). Postural Control in Deaf Children. Acta Medica Iranica, 55, 115-122.

Ennis, C. D. (2007). Defining Learning as Conceptual Change in Physical Education and Physical Activity Settings. Research Quarterly for Exercise and Sport, 78, 138-150.

Ercan, E. A., Kilic, A., Savas, S., Acak, M., Biyikli, Z., \& Tore, H. F. (2016). Deaf Athlete: Is There Any Difference beyond the Hearing Loss. Revista de Cercetare si Interventie Sociala, 52, 241-251.

FDA, US Food and Drug Administration (2018). Benefits and Risks of Cochlear Implants. https://www.fda.gov/MedicalDevices/ProductsandMedicalProcedures/ImplantsandPro sthetics/CochlearImplants/ucm062843.htm

Fiorini, M. L. S., \& Manzini, E. J. (2016). Concepção do professor de educação física sobre a inclusão escolar do aluno com deficiência. Debates em Educação, 8, 81-107. https://doi.org/10.28998/2175-6600.2016v8n15p81

Fiorini, M. L. S., \& Manzini, E. J. (2018). Strategies of Physical Education Teachers to Promote the Participation of Students with Hearing Impairment in Classrooms. Revista Brasileira de Educação Especial, 24, 183-198. https://doi.org/10.1590/s1413-65382418000200003

Frydrych, L. A. K. (2012). Revisiting the Concepts of Arbitrariness and Iconicity: Implications for the Linguistic Status of Sign Languages. ReVEL, 10, 282-294.

Gimenez, R. (2005). Physical Activity and Mental Deficiency. São Paulo: Phorte.

Gomes, M. C. (2010). O panorama actual da educação de surdos. Na senda de uma educação bilíngüe. Exedra, 3, 59-73. 
Gorla, J. I., \& Araujo, P. F. (2007). Motor Skills Assessment and Adapted Physical Education: KTK Test for the Mentally Handicapped. São Paulo: Phorte.

Haegele, J., Hodge, S., \& Filho, P. (2018). Brazilian Physical Education Teachers' Attitudes toward Inclusion before and after Participation in a Professional Development Workshop. European Physical Education Review, 24, 21-38.

Haywood, M. K. (1986). Life Span Motor Development (6th ed.). Champaign: Htiman Kinetics.

Hoffman, H. J., Dobie, R. A., Ko, C. W., Themann, C. L., \& Murphy, W. J. (2010). Americans Hear as Well or Better Today Compared with 40 Years Ago: Hearing Threshold Levels in the Unscreened Adult Population of the United States, 1959-1962 and 1999-2004. Ear and Hearing, 31, 725-734. https://doi.org/10.1097/AUD.0b013e3181e9770e

Kaga, K., Shinjo, Y., Jin, Y., \& Takegoshi, H. (2008) Vestibular Failure in Children with Congenital Deafness. International Journal of Audiology, 47, 590-599. https://doi.org/10.1080/14992020802331222

Kohl III, H. W., \& Cook, H. D. (2013). Committee on Physical Activity and Physical Education in the School Environment; Food and Nutrition Board; Institute of Medicine. Washington DC: The National Academies Press.

Kunz, E. (1991). Educação Física: Ensino \& mudanças. Ijuí: Unijuí.

Kurkova, P., Scheetz, N., \& Stelzer, J. (2010). Health and Physical Education as an Important Part of School Curricula: A Comparison of Schools for the Deaf in the Czech Republic and the United States. American Annals of the Deaf, 155, 78-95.

https://doi.org/10.1353/aad.0.0132

Lewis, S., Higham, L., \& Cherry, D. B. (1985). Development of an Exercise Program to Improve the Static and Dynamic Balance of Profoundly Hearing-Impaired Children. American Annals of the Deaf, 130, 278-284. https://doi.org/10.1353/aad.2012.1020

Lieberman, L. J., \& Cowart, J. F. (1996). Games for People with Sensory Impairments: Strategies for Including Individuals of All Ages. Champaign: Human Kinetics.

Lieberman, L. J., Volding, L., \& Winnick, J. P. (2004). Comparing Motor Development of Deaf Children of Deaf Parents and Deaf Children of Hearing Parents. American Annals of the Deaf, 149, 281-289.

Lima, F., De Falco, V., Baima, J., Carazzato, J. G., \& Pereira, R. M. (2001). Effect of Impact Load and Active Load on Bone Metabolism and Body Composition of Adolescent Athletes. MedSci Sports Exercise, 33, 1318-1323.

https://doi.org/10.1097/00005768-200108000-00012

Majlesi, M., Farahpour, N., Azadian, E., \& Amini, M. (2014). The Effect of Interventional Proprioceptive Training on Static Balance and Gait in Deaf Children. Research in Developmental Disabilities, 35, 3562-3567. https://doi.org/10.1016/j.ridd.2014.09.001

Manoel, E. J. (1996). The Study of the Motor Behavior of the Person with Disability: Problems and Questions. Brazilian Journal of School Health.

Mantoan, M. T. E. (2009). O desafio das diferenças nas escolas. Petrópolis, RJ: Vozes.

Mavilidi, M. F., Ruiter, M., Schmidt, M., Okely, A. D., Loyens, S., Chandler, P., \& Paas, F. (2018). A Narrative Review of School-Based Physical Activity for Enhancing Cognition and Learning: The Importance of Relevancy and Integration. Frontiers in Psychology, 9, 2079. https://doi.org/10.3389/fpsyg.2018.02079

Mayberry, R. I. (2002). Handbook of Neuropsychology (Chapter 4, 2nd ed., Vol. 8, Part II).

Melmer, A., Kempf, P., \& Laimer, M. (2018). The Role of Physical Exercise in Obesity and 
Diabetes. Praxis, 107, 971-976. https://doi.org/10.1024/1661-8157/a003065

Mendes, M. I., \& Nóbrega, T. P. (2009). Cultura de movimento: Reflexões a partir da relação entre corpo, natureza e cultura. Pensar a prática, 12. https://doi.org/10.5216/rpp.v12i2.6135

Mithen, S. (2005). The Singing Neanderthals - The Origins of Music, Language, Mind and Body. London: Weidenfeld \& Nicolson, The Orion Publishing Group Ltd.

Mourão, C. (2008). Ensinando educação física para surdos: Análise de caso. In 3th Seminário Brasileiro de Estudos Culturais e Educação (pp. 1-12). Porto Alegre,/RS: Plannertec Informática e Sistemas Ltda.

Munoz, M. T., de la Piedra, C., Barrios, V., Garrido, G., \& Argente, J. (2004). Changes in Bone Density and Bone Markers in Rhythmic Gymnasts and Ballet Dancers: Implications for Puberty and Leptin Levels. European Journal of Endocrinology, 151, 491-496. https://doi.org/10.1530/eje.0.1510491

Munster, M. A. V. (2011). Educação física especial e adaptada. Batatais: Ação Educacional Claretiana.

Newell, K. M. (1993). Coordination, Control and Skill. In K. M. Newell, \& D. M. Corcos (Eds.), Variability and Motor Control (pp. 295-317). Champaign: Human Kinetics.

Ortiz, I. R. R. (2008) Lipreading in the Prelingually deaf: That Makes a Skilled Speechreader? Spanish Journal of Psychology, 11, 488-502.

Pedreira, S. M. F. (2007). Educação de surdos na escola inclusiva e interculturalismo: Uma aproximação necessária. Revista Espaço, Rio de Janeiro, 27, 20-29.

Pettersson, U. et al. (2000). Effect of High Impact Activity on Boné Mass and Size in Adolescent Female: A Comparative Study between Two Different Types of Sports. Calcified Tissue International, 67, 207-214. https://doi.org/10.1007/s002230001131

Quadros, R. M. (1997). Educação de surdos-A Aquisição da Linguagem. Porto Alegre: Artmed.

Reis, V. P. F. (1992). A criança surda e seu mundo: O estado da arte, as políticas e intervenções necessárias. Dissertação de mestrado, Vitória: Universidade Federal do Espírito Santo.

Rizkallah, Z. Y. (1991). As oportunidades educacionais que se oferece a uma criança deficiente auditiva no município de São Paulo, pró-fono 3, 31-42.

Rocha, S. (1997). Revista Espaço: Edição Comemorativa 140 anos. Ed. Líttera.

Sarma, A. S. (2017). A Critical Review on Benefits of Different Physical Education Programs in School. International Journal of physical Education, Sports and Health, 4, 86-88.

Serbetar, I. (2014). The Role of Dynamic Systems in Motor Development Research: Just a Metaphor or a Notable Reality? Annales Kinesiologiae, 5, 113-121.

Sherrill, C. (2004). Adapted Physical Activity, Recreation, and Sport. Boston: McGraw-Hill.

Smith, L. B., \& Thelen, E. (1993). MIT Press/Bradford Books Series in Cognitive Psychology. A Dynamic Systems Approach to Development: Applications. Cambridge, MA: The MIT Press.

Squires, R. W., Shultz, A. M., \& Herrmann, J. (2018). Exercise Training and Cardiovascular Health in Cancer Patients. Current Oncology Reports, 20, 1-20. https://doi.org/10.1007/s11912-018-0681-2

Stafford, D. E. (2005). Altered Hypothalamic-Pituitary-Ovarian Axis Function in Young Female Athletes. Treatments in Endocrinology, 4, 147-154.

https://doi.org/10.2165/00024677-200504030-00003 
Stewart, D., \& Ellis, M. (1999). Physical Education for Deaf Students American. American Annals of the Deaf, 144, 315-319. https://doi.org/10.1353/aad.2012.0285

WHO, World Health Organization (2019). Global Strategy on Diet, Physical Activity and Health. https://www.who.int/dietphysicalactivity/pa/en/

Zaccagnini, K. J. (2005). How Physical Education Teacher Education Majors Should Be Prepared to Teach Students with Hearing Loss: A National Needs Assessment. American Annals of the Deaf, 150, 273-282. https://doi.org/10.1353/aad.2005.0038

Zaghetto, A. A. (2013). Deaf Musical Dimension: Reality or Utopia (pp. 1-6).

Zeng, N., Ayyub, M., Sun, H., Wen, X., Xiang, P., \& Gao, Z. (2017). Effects of Physical Activity on Motor Skills and Cognitive Development in Early Childhood: A Systematic Review. Biomed Research International, 2017, Article ID: 2760716.

https://doi.org/10.1155/2017/2760716

Zwierzchowska, A., Gawlik, K., \& Grabara, M. (2004). Energetic and Coordination Abilities of Deaf Children. Journal of Human Kinetics, 11, 83-92. 